\title{
A READING OF WHITMAN'S "PASSAGE TO INDIA"
}

\author{
Harsharan Singh Ahluwalia
}

No OTHER POEM by Walt Whitman has suffered such changes in fortune as "Passage to India." For the neo-humanists, with the history-of-ideas approach, "Passage to India" is the peak of Whitman's achievement. Immature and unsure of himself in the earlier poems, Whitman grows and develops into a Poet-Prophet with a vision of world unity in "Passage to India." Floyd Stovall's "Main Drifts in Whitman's Poetry," written 46 years ago, has been the most influential article in this phase of criticism. However, the aesthetic approach to Whitman's poetry resulted in a shift of emphasis from the later poems to some earlier ones. This change began with the centenary of the first edition of Leaves of Grass when some critics - mainly of the younger generation-called "Passage to India" inferior as poetry to earlier pieces which in their first published version seemed fresher and more powerful. Later Roy Harvey Pearce in his facsimile of the third edition emphasized the form and craftsmanship of poems of 1860 . The status of later poetry went further down when Richard Chase declared that in "Passage to India" Whitman has "given up poetry and become a speechmaker."2

More recently, Arthur Golden, working with the Lion MS, demonstrated that Whitman "had put 'Passage to India' together in patchwork fashion, and it shows." According to him only Sections 1, 2 (excluding "Fables"), 3, $4,6,8$, and 9 relate thematically; while "Fables" (11. 18-29), "O vast Rondure" (11. 81-115) and Section 7 (the first two were originally unpublished independent poems) are at odds with the theme of the poem. Pointing out stylistic weaknesses, Mr. Golden adds, "All too often Whitman slides into a dreadful succession of clichés reinforced with exclamatory flourishes." 3

Undoubtedly "Passage to India" has neither the freshness of "Song of Myself" nor the craftsmanship of "Out of the Cradle Endlessly Rocking" or "When Lilacs Last in the Dooryard Bloom'd," but the thematic coherence and richness of imagery argue for its inclusion among Whitman's successful works. The form of the poem is that of a rhapsody in which images and motifs are repeated to lead the reader in one fairly clear direction. The purpose of this essay is to give a coherent reading of "Passage to India," bringing out the richness of imagery which Whitman uses strategically to involve the reader in the prophecy of the poem.

"Singing my days"4 or "A worship new I sing" do not suggest the voice of an epic poet as some critics believe, ${ }^{5}$ but the voice of a singer. To identify the voice in the opening of "Passage to India" with the Poet's voice and the subject of his singing as the theme of the poem is to forget that the Poet, the 
true son of God, is announced later. Generally speaking, the status of the singer in Whitman and in all romantic poetry is inferior to that of the Poet. "Song of the Answerer" clarifies the difference between the two. Singers are born at frequent intervals but the true Poet appears only after centuries. Singers of each of the successive hours sing of the separate functions of life (each taking his name from that aspect of life of which he sings) whereas the Poet celebrates the wholeness of life. To quote from "Song of the Answerer":

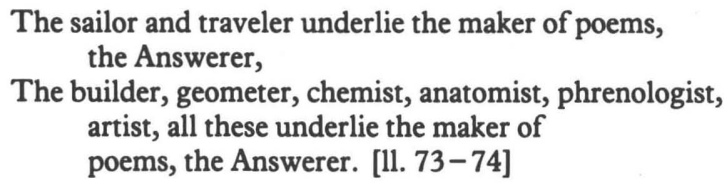

In Emerson's terms, the singers are "partial men" while the Poet is "the Complete Man." More than singing about the wholeness of life, the Poet brings wholeness and harmony into the universe. After he has put "things in their attitudes," gaps are bridged; no part counteracts another. With harmony thus achieved in the world seen, the Poet takes the reader to the world unseen, beyond death, to understand the meaning of cosmic events. In "Song of the Answerer," published in 1856, there is no merging with God as in "Passage to India": after the death the reader becomes a star "to sweep through the ceaseless rings and never be quiet again" (1. 83). In "Passage to India," it is neither the singer nor the Poet alone but a double speaker: the singer is dominant in the beginning, but towards the end the Poet gradually emerges to recover the lost paradisal state for mankind.

In the opening of the poem, the speaker admires the three technological achievements of the 19th-century-the Suez Canal, the Pacific Railroad, and the Atlantic Cable, which are juxtaposed to the spiritual accomplishments of the Poet. The material achievements of the past are not mentioned as in Section 6 (1l. 130-142) because the contrast evoked here is not between the past and the present (as the image of a "projectile" shows) but between the two kinds of achievements, material and spiritual, only one of which has been completed by the New World. In fact, the two achievements are characterized in two different "planes" of imagery-one horizontal and another vertical. The scientific achievements cover horizontal distances, the linking of East and West; the spiritual achievements of the past, on the other hand, have been characterized on a vertical plane from the depths of soul to the heights of heaven. Notice the imagery in which the spiritual achievements are celebrated:

The far-darting beams of the spirit, the unloos'd dreams;

The deep diving bibles and legends,

The daring plots of the poets, the elder religions;

$O$ you temples fairer than lilies pour'd over by the rising sun! 
O you fables spurning the known, eluding the hold of the known, mounting to heaven!

You lofty and dazzling towers, pinnacled, red as roses, burnish'd with gold!

Towers of fables immortal fashion'd from mortal dreams! [11. 21-27]

The temples of religions and the celestial towers of fables are pointing upwards toward heaven, emphasizing man's yearning for spiritual knowledge. The poets and religious philosophers of the past, "eluding the hold of the known," dreamed conceptions of God which are incorporated in the legends, epics and bibles of the ancient religions.

Coming back to the achievements on the horizontal plane, the speaker discerns God's purpose in the evolution of the universe toward harmony and unity. In furthering this goal, the explorers, engineers, and the architects have played a major part. They have geographically connected the old world with the new "not for trade or transportation only, / But in God's name, for thy sake O soul" (11. 39-40), that is to say, to realize the purpose of a united world. Their activity implicitly amounts to a new way of worshipping God, though they are unaware of their worship. It is comprehended and articulated by the speaker. But this worship performed by the scientists and engineers is a partial worship because they have fulfilled God's intention only on the horizontal plane.

This leads to Section 3, where in two striking pictures, the "tableaux twain," the poet depicts the opening of the Suez Canal, and the completion of the Pacific Railroad, both connecting East and West, both enhancing material progress. The speaker first watches from a distance the procession of a steamship through the Suez Canal and then advances to the deck to become a part of the scene. Similarly, in the next tableau, he changes from a distant observer of the train to a train passenger. Progressing thus in horizontal space, the speaker seems to dominate space, which implies that man has mastered physical distance. The railroad links "the Eastern to the Western sea" and through the Suez Canal, it serves as the "road between Europe and Asia" (11. 63 and 64), thus accomplishing, as he says in the next section, the "rondure of the World" (1. 80). This section ends with the speaker parenthetically exclaiming that the passage to India achieved by the 19th-century engineers and technologists is the fulfillment of the dream of Columbus many centuries after his death.

The deferred dream of Columbus - an important theme in "Passage to India"-leads the speaker to explore the role of dreams and ideas in history. Visualizing a "ceaseless thought, a varied train" (1. 74) moving along the slopes of history, he emphasizes that the struggles, sacrifices, experiences, knowledge and inspiration of former voyagers all have led to the accomplishment of the goal. Man's persistent efforts have unified the world.

The physical completion of the "rondure of the world" makes the mind of the speaker turn to the Edenic myth and perceive that the technological 
achievements of the nineteenth century have fulfilled the condition for spiritual accomplishments. In a Miltonic vision, he describes the beautiful globe "swimming in space" when Adam and Eve walked in the Garden of Eden in Asia. They and their "myriad progeny" are characterized in terms of feverish and baffled activity, incessantly repeating the sad refrain, "Wherefore unsatisfied soul? and Whither $O$ mocking life?" (1. 92). Troubled by the question of restless humanity, the speaker compassionately asks,

Ah who shall soothe these feverish children?

Who justify these restless explorations?

Who speak the secret of impassive earth?

Who bind it to us? what is the separate Nature so unnatural?

What is this earth to our affections? (unloving earth, without a throb to answer ours, Cold earth, the place of graves.) [11. 93-98]

He clearly sees that man, once in harmony with Nature and God, has now lost this state of unity. Earth is now "impassive" to man, and Nature is "separate" and "unnatural." Far from being a loving place, the earth is but the "cold earth, the place of graves." The speaker is one of these feverish children (note the first person plural "us" and "our" in the context of the above lines); therefore, he cannot answer the questions of the people; he can neither soothe them, nor justify their explorations, nor speak the secret of the earth. He knows, however, that "the first intent remains, and shall be carried out" (1. 99) after the captains, engineers, scientists, and others have completed their job of physically uniting the world. The time has "perhaps" come, the singer feels, for the fulfillment of his prophecy.

In a tone of celebration, the speaker goes on to announce the coming of the Poet whose mission is described in the following lines:

Then not your deeds only $O$ voyagers, $O$ scientists and inventors, shall be justified,

All these hearts as of fretted children shall be sooth'd,

All affection shall be fully responded to, the secret shall be told,

All these separations and gaps shall be taken up and hook'd and link'd together,

The whole earth, this cold, impassive, voiceless earth, shall be completely justified,

Trinitas divine shall be gloriously accomplish'd and compacted by the true son of God, the poet,... .

Nature and Man shall be disjoin'd and diffused no more,

The true son of God shall absolutely fuse them. [11. 106-111, 114-115]

Daringly called the "true son of God," the new Poet is both a prophet and a visionary. By his accomplishments on the spiritual plane, he will justify the 
deeds of the scientists and inventors on the material plane. With Christ-like healing power, he will soothe the hearts of mankind. By fusing Nature and Man, he will fill the gap between the material and the spiritual. His most glorious performance would indeed be to accomplish "Trinitas divine," consisting of God, Man and Nature. The true son of God, the Poet, will overcome the actual conditions of human life in the fallen state and restore man to the paradise in which God as well as the natural objects will have the same relationship which they had with Adam in the prelapsarian state. This is the "secret," God's purpose, which has been hidden from man but now stands revealed.

In Section 6 the speaker reiterates that the condition for the coming of the Savior has been fulfilled. Once again he sings of the physical union of the world which seems to have been accomplished. The controlling image of his singing is marriage. There are triadic images reminiscent of the "Trinitas divine" in the preceding section: the marriage of continents, climates and ocean; Europe, Asia and Africa, and they to the New World. There is no need for the Doge of Venice to wed Venice with the Adriatic, for the land and water are married by the scientists and engineers in the "vast terraqueous globe" (1. 119).

In earlier times also, the Poets appeared when this condition was fulfilled. On the "shores of America walking today" the speaker imaginatively brings the "retrospect" forward and reviews the accomplishments of ancient and medieval times. Before the discovery of the new world, the old world was also united by warriors like Alexander, Tamerlane and Aurungzeb, traders and explorers like Marco Polo and Batouta the Moor. The explorations of the Poets and Prophets on the vertical plane resulted in high accomplishments. Celebrated at some length in Section 2, the spiritual achievements of the past are here cryptically summed up in the line, "The flowing literatures, tremendous epics, religions, castes" (1. 134) and in the names of "old occult Brahma" and "the tender and junior Buddha." It must be noted, however, that the spiritual accomplishments of the past were limited. Though concerned with the mystery of God, the ancient poets and prophets were not able to recover the paradisal situation. The Poet-Prophet of the modern times will be more daring in his flights. The greater achievements on the physical plane call for greater accomplishments on the spiritual plane, which is nothing less than abolishing the effects of the fallen state and recovering the lost Paradise both within and outside.

The geographical unity achieved in earlier times was superficial. Man was not satisfied because there still were "Doubts to be solv'd, the map incognita, blanks to be fill'd" (1. 140). The efforts of the restless explorers continued. Columbus, "the chief histrion" who on his way to find a passage to India discovered the new world, is never absent from the thoughts of the speaker because he represents what in his notebook entry Whitman called 
"the spinal idea" of the poem. Reviewing now the career of Columbus after the passage to India has been found, the speaker wonders if the deferment of his vision is not like a seed which may lie "unwreck'd" for centuries in the ground. A vision never dies; it remains, until in God's good time "it sprouts, blooms, / And fills the earth with use and beauty" (11. 163-164). Dreams and prophecies may be deferred but they are fulfilled in due course. By extension, the implication of the references to the vision of history, Columbus and passage to India is that the dreams and prophecies on the spiritual plane would also be fulfilled. 6

With Section 7 there is a change in the "I" signified by the fast and restless rhythm and urgent and joyous tone. In place of celebrating the achievements of his day, justifying the deferment, and announcing the coming of the Poet, the speaker becomes active. Indeed, he has emerged as the PoetSavior. Such metamorphic changes are a common romantic device. Apollo becomes a god in Keats's Hyperion when he reads "the wondrous lesson" in the face of Mnemosyne. In Shelly's Prometheus Unbound, Prometheus and Asia are transfigured and Jupiter becomes powerless when Prometheus withdraws his curse. In "Passage to India" the singer passes into the Poet after the achievements on the horizontal plane have been completed, and lands have been "welded" together. Not that the Son of God has arrived from above: it is as if John the Baptist, who was announcing the coming of the Son, has become one with the Son of God.

To perform his functions, the Poet with his companion soul must first make a passage to "primal thought." As he explicitly states, this voyage is not a physical voyage on land and sea, but a voyage of the "mind's return, I To reason's early paradise" (11. 171-172). This prelapsarian paradise is inward. Man, following the Poet on this inward journey, will be able to recover his innocence and re-establish harmonious relationship with the "fair creation." Again, the "reason's early paradise" is not the lower faculty of sensory impressions; rather, it is that of intuition, the faculty of the visionary. It is with this faculty that the Poet and his soul launch out to God. The metaphor of sailing used for material advancement has been continued for spiritual accomplishments also. But sailing on the "waves of ecstasy" in the "seas of God" of "unknown shores" will have to be on the vertical plane if the Poet has to sound below the "Sanscrit and the Vedas" (1. 228), or to make a passage to "sun and moon and all you stars! Sirius and Jupiter" (1. 240), and to mount to God for a mystical union. The movement remains upwards whether the metaphor shifts from sailing to mounting, or from sailing to flying: "Are thy wings plumed indeed for such far flights?" (1. 225). To correspond to the material achievements and the geographical unity accomplished on the horizontal plane, this movement on the vertical plane will be spiralin "ceaseless rings," to use Whitman's favorite phrase. 
The Poet-Savior, unlike the old poets and priests, is eclectic in his conception of God:

Ah more than any priest $\mathrm{O}$ soul we too believe in God,

But with the mystery of God we dare not dally. [11. 185-186]

In the following address he refers approvingly to different versions of God as conceived in various "budding bibles" of the past.

O Thou transcendent,

Nameless, the fibre and the breath,

Light of the light, shedding forth universes, thou centre of them,

Thou mightier centre of the true, the good, the loving,

Thou moral, spiritual fountain-affection's source-thou reservoir, ... [11. 194-198]

There is the Buddhist idea of God as an unknowable mystery; the Deist idea of God as the creator and mover; the pantheistic idea of God as the breath and pulse of the universe; and the anthropomorphic God as "Comrade perfect" (1. 200). The spiritual journey is not only to God but through God.

In the spiritual exploration, the self of the Poet shrivels at the thought of God and the enigmas of Time, Space and Death. But his soul, which is his "actual Me," instead of shriveling, expands.

... thou gently masterest the orbs,

Thou matest Time, smilest content at Death,

And fillest, swellest full the vastness of Space [11. 209-211]

The soul, because it partakes of the eternal and the infinite, knows the subordinate nature of Time, Space and Death. Once the self has dissolved, the soul will merge with God after a journey of spiritual exploration on the vertical plane. The actual experience of Divine union is imagined in the following lines:

Reckoning ahead $\mathrm{O}$ soul, when thou, the time achiev'd, The seas all cross'd, weather'd the capes, the voyage done, Surrounded, copest, frontest God, yieldest, the aim attain'd, As fill'd with friendship, love complete, the Elder Brother found, The Younger melts in fondness in his arms. [11. 219-223]

Toward the end of the poem, the Poet exhorts his soul to take an immediate passage:

Passage, immediate passage! the blood burns in my veins!

Away $\mathrm{O}$ soul! hoist instantly the anchor!

Cut the hawsers - haul out - shake out every sail! [11. 242-244] 
The metaphor of the ship becomes more pronounced as the poet urges his soul to grovel no longer in ignorance or daze itself with books,

For we are bound where mariner has not yet dared to go,

And we will risk the ship, ourselves and all. [11. 250-251]

As the poem closes the lines become shorter and exclamations become more frequent. The poet urges his soul to steer in the "trackless seas" and "the deep waters"; they are safe, for he reminds his soul, "are they not all the seas of God?" (1. 254). Imaginatively on the spiritual journey upwards, the Poet exhorts his soul in the last line of the poem, "O farther, farther, farther sail" (1. 255).

In "Passage to India" Whitman has created a myth that the Poet, the true son of God, is born when lands and people have been joined and man has made utmost material progress. God's purpose in the physical realm has been fulfilled, people and lands have been united; now the true Poet must come to complete God's hidden prophetic intention by recovering the paradisal state for mankind. The speaker emerges as the Poet-Prophet who makes an imaginative journey upwards for a mystical union with God. The heavenly ascension of the Poet and his soul is imaged as a spiral corresponding to the material accomplishments on the horizontal plane. Since the material accomplishments of the past were limited, the upward movement of the old Poets and Prophets did not result in the accomplishment of "Trinitas divine," but now that lands and people have been united, it is the whole globe as well as the individual soul that the upward spiral movement of the Poet links with heaven. The paradise which is restored to man is within as well as on earth. In this state, life will be renewed; Nature, Man and God will be harmonized; and man will live at peace with himself and with the surrounding universe. Matching the progress of the speaker from singer to Poet, the lines move from song to prophecy of the "true son of God" that man will regain the paradisal state-that though it may be deferred, the prophecy will be fulfilled.

Guru Nanak Dev University, Amritsar, India

\section{NOTES}

1 Floyd Stovall, "Main Drifts in American Poetry," American Literature, 4 (1937), 3-21.

2 Richard Chase, Walt Whitman Reconsidered (New York: Sloane, 1955), p. 9.

3 Arthur Golden, "Passage to Less than India: Structure and Meaning in Whitman's 'Passage to India," $P M L A, 88$ (1973), 1101.

4 All citations from "Passage to India" and "Song of the Answerer" are from Leaves of Grass, 
Comprehensive Reader's Edition, edited by Harold W. Blodgett and Sculley Bradley (New York: New York University Press, 1965), pp. 411-421 and 166-170.

5 For example, John Lovell, Jr., says, "In this effort he gets help from the poem's epic intent. The first words, 'Singing my days ...' are as much the sign of the epic as 'I sing of arms and the hero' or as 'That man, oh goddess, sing." "Appreciating Whitman: 'Passage to India,'" Modern Language Quarterly, 21 (1960), 135. See also David Daiches, "Walt Whitman: Impressionist Prophet," in Leaves of Grass One Hundred Years After, edited by Milton Hindus (Stanford: Stanford University Press, 1955), p. 120.

6 Note the following two entries in the "Passage to India" Notebook in the Oscar Lion Collection:

The spinal idea: That the divine efforts of heroes, and their ideas, faithfully lived up to, will finally prevail, and be accomplished however long deferred.

A main idea is that a brave heroic thought or religious idea, faithfully pursued, justifies itself in time, nor perhaps in its own way but often in grander ways.

(See B. R. McElderry, Jr., “The Inception of 'Passage to India,'” PMLA, 71 [1956], 838.) 